\title{
The Relationship between Organization Capital and Trade Structure
}

$$
\text { and Its Policy Enlightenment }
$$

\author{
Xiangyang $\mathrm{Ci}$ \\ School of Management and Humanities \\ Shanghai University of Electronic Power \\ Shanghai 200090, China \\ E-mail: cxy_1013@sina.com \\ Deyu Zhao \\ School of Social Development and Public Policy \\ Fudan University \\ Shanghai 200433, China
}

\begin{abstract}
Traditional international trade theory is mainly based on comparative advantage. In fact, structure of international trade is more complicated than what is illustrated by theory, which affects illustrating ability of traditional international trade theory. By introducing organizational capital and combing it with specialization and scale economy, this paper interpreted intra-industry and inter-industry trade and put forward relevant suggestions for policy.
\end{abstract}

Keywords: Organizational capital, Comparative advantage, Trade structure, Policy enlightenment

\section{Traditional international trade theory and its shortcomings}

Traditional international trade theory is mainly based on comparative advantage. David Ricardo's Theory of Comparative Cost and Theory of Comparative Advantage are evolved from differences of labor productivity between two countries in trade. In a $2 * 2 * 1$ model, two countries with different labor productivities trade for two kinds of goods. One country possesses comparative advantage over the other country in production of the two kinds of goods. Under this circumstance, the country with lower labor productivity will produce and export one kind of goods that has relatively less disadvantage in export (namely with comparative advantage). The country with higher labor productivity will perform quite the reverse. The H-O Theory emphasizes on difference of factor endowment instead of difference of labor productivity, thinking that structure of international trade takes difference of factor endowment as a precondition, and every country produces and exports the goods that chiefly consume domestic rich factors and imports the goods that intensively consume domestic scarce factors. H-O Theory still follows traditional comparative theory. Before the appearance of modern trade theory, trade theory is basically derived from H-O Theory, following the way of factor endowment. But Leontief paradox appears as people try to prove the H-O Theory. Later, lots of new theories come into being in order to explain the Leontief paradox. However, practical structure of international trade is more complicated than what is illustrated by theory. For example, before the World War II, the trade between developed countries and developing countries is dominant. But afterwards, it is the trade between developed countries that dominates the international trade, which surpasses the trade quota between developed countries and developing countries. Meanwhile, the trade between developing countries is growing. In the aspect of trade structure, trade between developed countries is mostly intra-industry trade. Changes of international trade structure contribute to the emergence of intra-industry trade theory that completely gives up the two fundamental assumptions of traditional trade theory, namely unchanging returns to scale and perfect competition market. The representative is Paul R. Krugman, an American economist. The intra-industry trade theory is based on increasing returns and imperfect competition, by which to explain the intra-industry trade. Some domestic scholars, such as Zengqiang Fan and Tao Shang (2006) bring organization capital into a comparative advantage framework to explain the developed countries' comparative advantages over developing countries in international trade and international value-chain division. In their opinion, human capital and organization capital are different factors that impact comparative advantage. From a macro viewpoint, they introduce organization capital into national trade analysis for an initial try, which explores the traditional comparative advantage theory. In fact, enterprises' comparative advantages serve as the micro base for the comparative advantages in international trade. 
Enterprises' organizational capital is an important factor forming comparative advantages in international trade. By introducing the organizational capital, this paper studies the relationship between organizational capital and international trade structure from micro and macro angles, and advances relevant policy suggestions.

\section{Organizational capital and international trade structure}

\subsection{Fundamental concepts of organizational capital}

The organizational capital concept can be traced back to Marshall in economic field. In analyzing the basic factors of production, Marshall (1961) regards organization as the fourth resource besides land, capital, and labor. Becker and Gordon (1966) take normal organization as a property form. In their opinion, the owner of normal organization is entitled to shape, change, dismiss, or sell the normal organization in order to reach certain goal. Therefore, to own normal organization means normal organization can be treated as property. Prescott and Visscher (1980) define organizational capital from an information angle. They think that the information about employees and tasks is a kind of asset for companies. Tomer (1987) analyzes the relationship between individuals and organization, from a human capital angle, chiefly focusing on the integration of individual gifts and individuals with the organization. He firstly divides human capital into enterprises' common human capital and special one. By combining with enterprises' other production factors, the special human capital can form different kinds of organizational capital. Edvinsson and Malone (1997) add organizational capital (includes innovation capital and procedure capital) into structural capital. Atkeson and Kehoe (2005), from a capital model aspect, regard enterprises' accumulated special knowledge as organizational capital. By studying American manufacturing industry, they conclude that the value generated by organizational capital is about two third of value of material capital.

In China, Junyi Weng (1999) begins a study on organizational capital relatively early. Following Tomer's thought, Junyi Weng (1999) regards organizational capital as the value existed in form of organizational capital and based on capital expenditure caused by organizational incentive and coordination. Zheng Fan (2002) thinks that organizational capital deposit is total organizational capital investment at certain moment, which reflects an enterprise knows how to coordinate its business activities. Organizational capital is also a force of an enterprise, which helps the enterprise avoid transferring this ability to competitors. Zengqiang Fan and Tao Shang (2006) agree that organizational capital is a factor connected closely with knowledge and human capital, emphasizing the impacts of effective and coordinative economic activities on organizational efficiency. Enterprises' organizational ability reflects the organizational capital. All views agree that enterprises' institutional regulations, organizational structure, organizational culture, and management structure are components of organizational capital.

In our opinion, organizational capital is the factor that hides in corporate operations and can generate added-values for an enterprise. It associates with specific organization and does not disappear due to leave of certain people. The enterprise that quite relies on key management talents or technological experts does not have strong organizational capital. An enterprise with strong organizational capital has intensive cohesion. Its organizational objectives are in accordance with individual goals to a great degree. Employees have high identification toward the organization. If employees leave the enterprise, what they take away is their individual capitals but not organizational capital. Organizational capital is an important factor that causes intra-industry specialization.

\subsection{Organizational capital and specialization}

Just as what discusses above, real international trade structure is more complicated than theory, especially the intra-industry trade between developed countries after the World War II. Comparative advantage theory can not explain new conditions effectively, but intra-industry trade theory can in a sense. We think that this trade structure is caused by organizational capital to a great degree. Take the automobile trade between America and Japan for example. America and Japan are both capital and technology-intensive countries. They have similar resource endowments in automobile production. Neither has prominent comparative advantage. According to the comparative advantage theory, America and Japan will not have intra-industry trade in automobile industry. But that conflicts with the facts of international trade. At 70s and 80s in last century, Japanese automobile has occupied more market shares in American automobile market, which has aroused the America-Japan trade friction. In 2004, the market occupation rate of Japanese automobile in American automobile market reaches 30\% (www. baidu.com, and www. pcauto.com.cn). American General Moters and Ford enter Japanese market either. Although Germany is an automobile giant, its domestic automobile market is also taken by foreign automobile. The market occupation rate of foreign automobile reaches a new top, 36.1\%, in 2006. In some new federal states, Toyota and Peugeot even occupy 50.5\% of market shares. In 2006, Toyota and Peugeot export 1,240,000 automobiles to Germany, rising 5.2\% than last year (Ministry of Commerce of PRC, from www. baidu. com). Indeed, the diversity of demand drives trade. But that is not the only reason. From an organizational capital angle, we think, in the automobile industry, enterprises have different organizational capital deposits, which will be internalized into products in an intangible way. As a result, products tend to have different qualities, styles, and costs, reflecting the diversity of products. Then, how does an organization achieve the diversity of products? In our opinion, organizations always have certain specialization and coordination. In a sense, any kind of economic organization is a 
synthesis of various specialization and coordination. Therefore, organizational capital associates with certain specialization. So, organizational capital deposits indicate the degree of specialization. An organization with effective specialization and coordination has strong organizational capital. That is the degree of internal specialization and coordination in an economic organization. Besides, there is another kind of specialization that surpasses one organization and spans different organizations, such as General Motors and Toyota's specialization in automobile production. Specialization leads to diversity of products, which can satisfy customers' needs better. Organizational capital results in inter-organizational specialization, which impacts organizational capital conversely. For example, America and Japan's specialization in automobile production drives more investments in relevant organizational capitals, which enhances and solidifies the comparative advantages of two countries in automobile industry.

Furthermore, for joint ventures, the organizational capital is different from each party but still connects with specialization. Take Shanghai Volkswagen, a Sino-Germany Joint Venture, for example. The investment ratios are: Saic Motor 50\%, Germany Volkswagen Group 40\%, and Volkswagen (China) Investment Co. Ltd. 10\%. The cooperation will last for 45 years, till the year 2030. Shanghai Volkswagen introduces technologies from Germany Volkswagen Group, adopts a production flow from Germany, and follows Germany Volkswagen Group's production management and quality management system, which makes Shanghai Volkswagen can achieve not only a spillover effect of technology but also a spillover effect of institutional capital from Germany Volkswagen Group, such as the precise quality, JIT delivery, and brand construction. On the other hand, Shanghai Volkswagen can also get a spillover effect of institutional capital from Saic Motor. But state-owned enterprise does not possess sufficient organizational capital deposit, which makes Shanghai Volkswagen fail to benefit more from Saic Motor. Institutional capital is an irreplaceable component of organizational capital. Therefore, as a joint venture, Shanghai Volkswagen inevitably possesses two parties' certain organizational capitals, but not a simple sum of two different organizational capitals. An organic combination of two organic capitals forms Shanghai Volkswagen's organizational capital, such as precise quality, JIT delivery, brand construction, and strong human capital deposit. Shanghai Volkswagen and its mother company, namely Saic Motor, and Germany Volkswagen Group realize the specialization and coordination in production scope, products brands, and products quality. Germany Volkswagen and Shanghai Volkswagen develop new-generation medium and high-class automobiles by cooperation, gradually bringing Shanghai Volkswagen's R\&D into Germany Volkswagen Group's global development system. Guangzhou Honda develops joint venture's self-owned brand, going far away than Shanghai Volkswagen.

\subsection{Organizational capital and international trade structure}

Apparently, organizational capital theory can well explain intra-industry trade phenomenon between developed countries. It complements the traditional comparative advantage theory. Next, considering the nature of industry, we analyze the relationship between organizational capital and international trade structure.

(1) Organizational capital and inter-industry trade. For inter-industry trade, organizational trade forms enterprises' comparative advantage to a greater degree. It can be explained by traditional comparative advantage theory. In other words, all parties that participate in international trade, based on exerting their comparative advantages, will export products that intensively consume domestic rich factors, and import products that intensively consume domestic scarce factors. Traditional trade is complementary and pursues to reach a complementary equilibrium, which has a self-reinforcement mechanism for a long period under the effect of path dependence mechanism. Therefore, the equilibrium is relatively stable. But if being affected by interfering factors (such as strategic trade policy), the original equilibrium will be broken and form new equilibrium. China's foreign trade (such as China-America trade, China-Europe trade) shows a kind of relative stable equilibrium. China's trade structure: China exports primary products, such as textiles, steels, and coats. These products are labor-intensive and resource-intensive. What China imports from Europe and America are mainly capital-intensive and technology-intensive products, such as Boeing airplanes, production machines and equipments. The complementary trade can form a relative stable equilibrium, which can explain why a trade war does not happen though trade frictions appear frequently in China-America trade and China-Europe trade. Because the complementary trade has a self-reinforcement mechanism, it further enhances different parties' comparative advantages respectively. Somebody has already warned China and India of same curse. That is, under the effect of path dependence mechanism, their low-cost advantages will restrain their further development. To break this equilibrium needs interfering factors. Along with the implementation of China's strategic trade policies and the upgrade of China's industrial structure, the complementary equilibrium will be broken inevitably.

(2) Organizational capital and intra-industry trade. For intra-industry trade, such as the intra-industry trade between developed countries, the introduction of organizational capital usually leads to imperfect competitive market structure. As far as the intra-industry international trade is concerned, take the automobile trade between America and Japan for example, because different enterprises (such as General Motors and Toyota) have different organizational capitals, different organizational capital deposit is one of important reasons for economy of scale. The two enterprises have different organizational institutions and cultures. From a viewpoint of organizational idea, General Motors stands for the 
free and open American style that can be identified in the design and production of automobile products. General Motors' designers continuously inject inspirations and passions into their designs that may turn into well-known automobiles later. General Motors' designers never stop their pursuits for perfect automobile design. No matter what it is the shape or the function, General Motors persist in continuous innovation and pursue for perfect all the time. Toyota is one of top ten automobile manufacturers in the world. Its products have won a wide popularity. Toyota adopts Deming production, decreasing production costs, realizing JIT delivery and zero inventories, and applying total quality management. The demand-driven production integrates the Fordism with individualized production together. It is the operational system that establishes the status of Toyota. However, Toyota's corporate culture that emphasizes on dedication and slow promotion generates unfavorable effects on the enterprise. For example, because of the left of senior managers who work in North America regions, Toyota's business grows slowly. See table 1.

From Table 1, we notice that General Motors mainly emphasizes on technological innovation and team cooperation. Toyota lays stresses on products orientation, namely the energy-saving and environment- friendly cars, and services. Germany Volkswagen Group gives priority to technology. Therefore, though all belong to the automobile industry, these enterprises can focus on their special field, realizing market segmentation. Toyota mainly develops energy-saving and environment-friendly cars and emphasizes on services. General Motors mainly produces large luxury automobiles and energy-saving cars. Volkswagen pays attention to design new cars, being a leader of automobile fashion. These automobile manufacturers exert their scale economic advantages in segment market. In a sense, just because enterprises make best use of self organizational capitals and realize specialization and coordination, economy of scale appears. For example, General Motors chiefly explore the market in North America and Europe, Toyota in Asia, and Volkswagen in new market. To be specific, Faw Toyota realizes the sales of RMB 400,000 in China in 2008. Meanwhile, General Motors and Volkswagen increase their investments in Chinese market. Due to China's market scale, they realize economy of scale either. In addition, the three automobile manufacturers export automobiles mutually, which drives the intra-industry trade of automobile industry between three countries. For example, in 70 s and 80 s last century, Japan exports a great number of cars to America, which causes a serious trade friction between the two countries. In order to make Japan restrain its exports, America even employs the federal government. Meanwhile, America improves its automobile exports to Japan. The inter-industry trade grows energetically.

\section{Enlightenments for China's foreign trade}

Organizational capital and international trade structure theory offer important enlightenments for China's foreign trade.

(1) Adjust trade structure and develop intra-industry trade. Today's international trade is: there is trade based on comparative advantages between developed countries and developing countries and also the intra-industry trade between developed countries, and the later is dominant. The former is mainly determined by comparative advantages, and the later organizational capitals. At present, China's foreign trade is based on comparative advantages, mainly exporting low value-added labor-intensive products, and importing high value-added technology-intensive products. This trade structure has ever greatly driven China's foreign trade, but also brought about more trade frictions. Terms of trade are worse for China. Because comparative advantages are dynamic, along with the improvement of Chinese enterprises' competence and the rise of China's position in international specialization, we should energetically develop intra-industry trade.

\section{(2) Increase investments in organizational capital}

In our opinion, organizational capital is the factor that hides in corporate operations and can generate added-values for an enterprise. It associates with specific organization and does not disappear due to leave of certain people. For a country, its enterprises' organizational capital deposits determine its trade structure and status to a great degree. Presently, China's textile enterprises possess high organizational capital deposits. And China's foreign trade surplus is mainly from this industry. Just as American and Japanese automobile enterprises, and American software enterprises possess high organizational capital deposits, which give them advantages in world automobile trade, China must increase investments in domestic enterprises' organizational capital deposits, which will exert profound effects on the improvement of China's terms of trade and the change of China's economic growth way.

(3) Continue to develop comparative advantages. Comparative advantages are still the base for China's foreign trade at present. A viewpoint is China's labor advantages can last 15 years. But others think that the pure labor-depended growth does not last. No matter how much China's labor advantages last, most people agree that low labor costs are still China's comparative advantages for a long time. Therefore, China's present trade structure based on comparative advantage theory is reasonable, which has been illustrated by the long-term foreign trade surplus. In China, the light industry and textile industry possess evident comparative advantages. However, comparative advantages are changeable. Along with the rising prices of certain factors, especially the price of labor, the prices of other factors, such as capitals, tend to dropping. Because of the long-last foreign trade bilateral surplus and the more than one thousand billion exchange reserve, capital is not scarce in China any more. It becomes a relative rich production factor. Therefore, comparative advantages are dynamic. We should develop China's comparative advantages from a dynamic angle. The 
trade between America and British in history well illustrates the dynamics of comparative advantages. Before the industrialization, America imported a great number of textiles, steels, steamers, and engines from British. And America provided with resources for British. But after the Industrial Revolution, especially after the Second Industrial Revolution, America turned into a country that exports these goods.

\section{References}

Fan, Zheng. (2002). Core Competence: Knowledge-Oriented Core Capability. Shanghai: Shanghai Jiaotong University Press.

Liu, Renhuai \& Long, Xiandong. (2007). Organization capital and its measurement. Finance and Accounting Monthly. No.8.

Liu, Haijian \& Long, Xiandong. (2007). Enterprise organizational capital, strategic perspective, and corporate performance. Management World. No.5.

Qiu, Jinmei. (2006). Entrepreneur and the building of a company's key competence-explanation of organizational capital and social capital. Journal of Southwest University of Science and Technology. No.23(6).

Fan, Zengqiang \& Shang, Tao. (2006). The introduction of organizational capital ------ an exploration of comparative advantage theory. Contemporary Economic Research. No.7.

Zhang, Qing. (2007). Commentary on organizational capital theory. Journal of Hunan College of Finance and Economics. No.23(108).

Gao, Debu \& Wang, Yu. (2006). World Economy History. Beijing: China Renmin University Press.

Wu, Qiong. (2008). Faw Toyota aims at reaching the sales of RMB 400,000 in China in 2008 and the real sales may be more. Shanghai Securities News. From http://www.qiche.com.cn. Feb. $29^{\text {th }}$.

Prescott E. C. \& Visscher M. (1980). Organization capital. Journal of Political Economy. No.88. p446- 4611

John F. Tomer. (1987). Organization capital ------ the path to higher productivity and well-being. Praeger Publisher.

Table 1. Several automobile enterprises' organizational capitals.

\begin{tabular}{|c|c|c|c|c|}
\hline \multirow[b]{2}{*}{ Name } & \multicolumn{2}{|c|}{ Organizational idea capital } & \multicolumn{2}{|c|}{ Organizational structure capital } \\
\hline & Corporate strategy & Corporate culture & $\begin{array}{l}\text { Ownership } \\
\text { structure }\end{array}$ & $\begin{array}{l}\text { Organizational } \\
\text { framework }\end{array}$ \\
\hline Toyota & $\begin{array}{lr}\text { Focus } & \text { on } \\
\text { energy-saving } & \text { and } \\
\text { environment-friendly } \\
\text { cars }\end{array}$ & $\begin{array}{lr}\begin{array}{l}\text { Care } \\
\text { "human }\end{array} & \text { about } \\
\text { resources" } & \\
\text { Emphasize } & \text { on } \\
\text { services } & \text { and } \\
\text { products } & \end{array}$ & Omit & $\begin{array}{l}\text { Lean-Production } \\
\text { organizational } \\
\text { structure }\end{array}$ \\
\hline General Motors & $\begin{array}{l}\text { Technology } \\
\text { innovation, develop } \\
\text { electronic } \\
\text { commerce, enhance } \\
\text { development of } \\
\text { environment-friendly } \\
\text { products and } \\
\text { technologies }\end{array}$ & $\begin{array}{l}\text { Center on } \\
\text { customers, } \\
\text { sincerity and } \\
\text { integrity, safety, } \\
\text { continuous } \\
\text { improvement and } \\
\text { innovation, } \\
\text { completely } \\
\text { empowered team } \\
\text { cooperation }\end{array}$ & Omit & $\begin{array}{l}\text { Close } \\
\text { organizational } \\
\text { framework }\end{array}$ \\
\hline Volkswagen & $\begin{array}{l}\text { Technology } \\
\text { innovation }\end{array}$ & $\begin{array}{l}\text { Technology-based } \\
\text { innovation, } \\
\text { emphasize on } \\
\text { leading } \\
\text { technologies }\end{array}$ & Omit & $\begin{array}{l}\text { Start } \\
\text { implement } \\
\text { localization }\end{array}$ \\
\hline
\end{tabular}

